\title{
Hubungan berat badan dengan tekanan darah pada siswa SMP di Kecamatan Pineleng
}

\author{
${ }^{1}$ Vicky M. Kalangie \\ ${ }^{2}$ Sarah M. Warouw \\ ${ }^{2}$ Adrian Umboh
}

\author{
${ }^{1}$ Kandidat Skripsi Fakultas Kedokteran Universitas Sam Ratulangi Manado \\ ${ }^{2}$ Bagian Ilmu Kesehatan Anak Fakultas Kedokteran Universitas Sam Ratulangi Manado \\ Email: mcp.vicqee@gmail.com
}

\begin{abstract}
Obesity is a condition that exceeds the relative weight of a person as a result of the accumulation of nutrients, especially carbohydrates, fats, and proteins. Hypertension is defined as systolic and diastolic blood pressures above than 95th percentile according to sex, age, and height. This study aimed to determine the relationship between body weight and blood pressure among junior high school students in Kecamatan Pineleng. This was an analytical study using a cross sectional approach. Population was junior high school students grades 7 and 8 aged 12-14 years of 3 Junior High Schools located in Kecamatan Pineleng. There were 75 samples obtained by using simple random sampling technique. The Chi-Square test showed a p value of $0.001(<0.005)$. Conclusion: There was a significant relationship between weight and blood pressure among junior high school students in Kecamatan Pineleng.
\end{abstract}

Keywords: weight, blood pressure.

\begin{abstract}
Abstrak: Obesitas adalah suatu keadaan yang melebihi dari berat badan relatif seseorang, sebagai akibat penumpukan zat gizi terutama karbohidrat, lemak dan protein. Hipertensi adalah tekanan darah sistolik dan diastolik yang melebihi persentil 95 menurut jenis kelamin, usia, dan tinggi badan. Penelitian ini bertujuan untuk mengetahui hubungan antara berat badan dengan tekanan darah pada siswa SMP di Kecamatan Pineleng. Penelitian ini menggunakan metode analitik dengan desain potong lintang. Populasi yang diambil ialah siswa SMP kelas 7 dan 8 yang berusia 12 - 14 tahun di 3 SMP yang berada di Kecamatan Pineleng. Jumlah sampel 75 siswa diperoleh dengan teknik simple random sampling. Hasil analisis dengan uji Chi-Square menyatakan nilai signifikansi 0,001 $(<0,005)$. Simpulan: Terdapat hubungan bermakna antara berat badan dengan tekanan darah pada siswa SMP di Kecamatan Pineleng.

Kata kunci: berat badan, tekanan darah.
\end{abstract}

Overweight dan obesitas adalah suatu keadaan yang melebihi dari berat badan relatif seseorang sebagai akibat penumpukan zat gizi terutama karbohidrat, lemak dan protein. Kondisi ini disebabkan oleh ketidakseimbangan antara konsumsi kalori dan kebutuhan energi, dimana konsumsi terlalu banyak dibandingkan dengan kebutuhan atau pemakaian energi. ${ }^{1}$
Overweight dan obesitas berhubungan dengan peningkatan mordibitas dan mortalitas karena hipertensi, diabetes, dislipidemia, kardiovaskular dan penyakit ginjal. $^{2}$

Obesitas pada masa anak-anak akan memiliki kecenderungan untuk menjadi obesitas pada masa dewasa muda yang berhubungan dengan masalah kesehatan di 
masa depan. Studi dari National Health And Medical Research Council (NHMRC) melaporkan bahwa obesitas pada masa anak-anak kira-kira lebih dari 50\% akan menjadi obesitas pada masa dewasa. ${ }^{3}$

Overweight dan obesitas ditandai dengan kelebihan lemak dalam tubuh. Obesitas dapat diukur menggunakan Indeks Massa Tubuh (IMT), sebuah rumus matematika untuk indeks berat-tinggi. IMT diukur dengan membagi berat badan dalam kilogram dengan tinggi dalam meter kuadrat $\left(\mathrm{kg} / \mathrm{m}^{2}\right)$. IMT memiliki korelasi yang tinggi dengan dengan kelebihan berat badan dan berat badan kurang pada tingkat populasi. ${ }^{4}$

Menurut U. S. Departement of Health and Human Service dalam The Fourth Report, hipertensi adalah tekanan darah sistolik dan diastolik yang lebih dari persentil 95 menurut jenis kelamin, usia, dan tinggi badan. Tekanan darah normal pada anak adalah tekanan darah sistolik (TDS) dan tekanan darah diastolik (TDD) di bawah persentil 90 berdasarkan jenis kelamin, usia dan tinggi badan. ${ }^{5}$

Hipertensi diketahui merupakan salah satu faktor resiko terhadap terjadinya penyakit jantung koroner pada orang dewasa, dan adanya hipertensi pada masa anak dapat berdampak dalam perkembangan dini penyakit jantung koroner tersebut. Pengukuran tekanan darah secara rutin berguna untuk deteksi hipertensi pada anak sedini mungkin. Tekanan darah normal anak-anak bervariasi karena banyak faktor mempengaruhinya antara lain usia, jenis kelamin, tinggi dan berat badan. Edukasi, deteksi dini, diagnosis yang akurat dan terapi yang tepat akan memperbaiki kesudahan (outcome) jangka panjang untuk anak-anak dan remaja yang menderita hipertensi. ${ }^{6}$

Berdasarkan data World Health Organization (WHO), selama tiga dekade terakhir prevalensi overweight dan obesitas meningkat secara substansial. Secara global, diperkirakan 170 juta anak-anak (usia kurang dari 18 tahun) kini diperkirakan kelebihan berat badan. ${ }^{7}$ Penelitian Halbach dan Flynn tahun 2013 di Amerika menunjukkan bahwa epidemik obesitas telah menjadi perhatian bersama para dokter anak, dengan estimasi sebesar 32\% anak-anak di Amerika Serikat yang diklasifikasikan berat badan lebih dan 18\% obesitas. $^{8}$ Data yang diperoleh dari Australian Health And Fitness Survey menyatakan bahwa prevalensi obesitas pada anak usia 6-17 tahun di Amerika Serikat dalam tiga dekade terakhir meningkat dari 7,6-10,8\% menjadi 13-14\%, prevalensi overweight dan obesitas pada anak usia 6-18 tahun di Rusia adalah 6\% dan $10 \%$, di Cina adalah 3,6\% dan 3,4\% dan di Inggris adalah $22-31 \%$ dan $10-17 \%$, bergantung pada umur dan jenis kelamin. Sedangkan prevalensi obesitas pada anakanak sekolah di Singapura meningkat dari 9\% menjadi 19\%. ${ }^{3}$ Di Indonesia, Hasil Riset Kesehatan Dasar Nasional (Riskesdasnas) Tahun 2010 menunjukkan bahwa prevalensi kegemukan pada anak umur 13-15 tahun adalah 2,5\% dari total populasi dan anak umur 16-18 tahun adalah $1,4 \%$ dari total populasi. Terdapat 11 provinsi yang memiliki prevalensi kegemukan pada anak 16-18 tahun diatas prevalensi nasional, salah satunya adalah provinsi Sulawesi Utara. ${ }^{9}$

Menurut data World Health Organization (WHO) tahun 2013, pada tahun 2009 sampai 2010, 85,5\% dari anakanak dan 44,3\% dari dewasa memenuhi hipertensi. Prevalensi hipertensi tertinggi di wilayah Afrika yaitu 46\% dari orang dewasa berusia 25 tahun keatas, sedangkan prevalensi terendah yaitu 35\% ditemukan di Amerika. Penelitian yang dilakukan oleh American Heart Associationtahun 2014 juga menyatakan bahwa tekanan darah tinggi terdaftar disertifikat kematian sebagai penyebab utama 63.119 kematian di Amerika pada tahun 2010. ${ }^{10}$ Sinaiko et al, dalam penelitiannya terhadap 14.686 orang anak berusia 10-15 tahun menemukan 4,2\% anak mengalami hipertensi. Penelitian yang dilakukan oleh 
Saing $^{11}$ pada tahun 2005 menyatakan bahwa angka prevalensi kejadian hipertensi pada anak dan remaja di Indonesia bervariasi dari angka 3,11\% sampai 4,6\%.

\section{METODE PENELITIAN}

Penelitian ini menggunakan metode observasional analitik dengan desain potong lintang. Populasi dan sampel dalam penelitian ini seluruh seluruh siswa SMP kelas 7 dan 8 yang berusia 12 - 14 tahun di 3 Sekolah Menengah Pertama yang berada di Kecamatan Pineleng yakni: SMP Negeri 1 Pineleng, SMP Negeri 2 Pineleng, dan SMP St. Fransiskus Xaverius Pineleng yang memenuhi kriteria inklusi dan bersedia menjadi objek penelitian. Jumlah sampel yang diperoleh 75 siswa.

\section{HASIL PENELITIAN}

Tabel 1 memperlihatkan bahwa responden berjenis kelamin perempuan berjumlah lebih banyak yaitu 40 orang (53,3\%) dibandingkan responden berjenis kelamin laki-laki dengan jumlah 35 orang (46,7\%).

Tabel 1. Distribusi Karakteristik Responden Menurut Jenis Kelamin.

\begin{tabular}{ccc}
\hline Jenis Kelamin & $\mathrm{n}$ & $\%$ \\
\hline Laki-Laki & 35 & 46,7 \\
Perempuan & 40 & 53,3 \\
\hline
\end{tabular}

Tabel 2. Distribusi Karakteristik Responden Menurut Umur.

\begin{tabular}{ccc}
\hline Umur & $\mathrm{n}$ & $\%$ \\
\hline 12 Tahun & 19 & 25,3 \\
13 Tahun & 37 & 49,3 \\
14 Tahun & 15 & 20,0 \\
15 Tahun & 4 & 5,3 \\
\hline
\end{tabular}

Tabel 2 memperlihatkan bahwa responden terbanyak berusia 13 tahun sebanyak 37 orang (49,3\%), diikuti responden yang berusia 12 tahun sebanyak 19 orang (25,3\%), responden yang berusia 14 tahun sebanyak 15 orang (20\%) dan responden yang berusia 15 tahun sebanyak 4 orang $(5,3 \%)$.

Tabel 3 menunjukkan responden terbanyak ialah dengan berat badan 51-60 kg yaitu 28 orang (37,3\%), sedangkan responden dengan berat badan lebih dari 80 kg sebanyak 1 orang (1,3\%).

Tabel 3. Distribusi Karakteristik Responden Menurut Berat Badan.

\begin{tabular}{ccc}
\hline Berat Badan & $\mathrm{n}$ & $\%$ \\
\hline$<40 \mathrm{Kg}$ & 11 & 14,7 \\
$41-50 \mathrm{Kg}$ & 7 & 9,3 \\
$51-60 \mathrm{Kg}$ & 28 & 37,3 \\
$61-70 \mathrm{Kg}$ & 25 & 33,3 \\
$71-80 \mathrm{Kg}$ & 3 & 4,0 \\
$>80 \mathrm{Kg}$ & 1 & 1,3 \\
\hline
\end{tabular}

Pada Tabel 4, yang terbanyak ialah responden dengan tinggi badan 151-150 cm yaitu 39 orang (52\%), sedangkan responden yang memiliki tinggi badan $>160 \mathrm{~cm}$ ialah 7 orang $(9,3 \%)$.

Pada Tabel 5 yang terbanyak ialah responden dengan overweight yaitu 37 orang $(49,3 \%)$, sedangkan responden dengan underweight sebanyak 3 orang $(4 \%)$.

Tabel 4. Distribusi Karakteristik Responden Menurut Tinggi Badan.

\begin{tabular}{ccc}
\hline Tinggi Badan & $\mathrm{n}$ & $\%$ \\
\hline$<150 \mathrm{~cm}$ & 29 & 38,7 \\
$151-160 \mathrm{~cm}$ & 39 & 52,0 \\
$>160 \mathrm{~cm}$ & 7 & 9,3 \\
\hline
\end{tabular}

Tabel 5. Distribusi Karakteristik Responden Menurut Hasil Pengukuran IMT.

\begin{tabular}{ccc}
\hline IMT (Persentil) & $\mathrm{n}$ & $\%$ \\
\hline$<5$ (Underweight) & 3 & 4,0 \\
5-84 (Normal) & 13 & 17,3 \\
85-94 (Overweight) & 37 & 49,3 \\
$>95$ (Obesitas) & 22 & 29,3 \\
\hline
\end{tabular}

Pada Tabel 6, responden terbanyak 
ialah dengan pengukuran sistolik 120 yaitu 27 orang (36\%), sedangkan responden dengan pengukuran sistolik 140 sebanyak 3 orang (4\%).

Tabel 6. Distribusi Karakteristik Responden Menurut Hasil Pengukuran Sistolik.

\begin{tabular}{ccc}
\hline TD Sistolik & $\mathrm{n}$ & $\%$ \\
\hline 100 & 10 & 13,3 \\
110 & 22 & 29,3 \\
120 & 27 & 36,0 \\
130 & 13 & 17,3 \\
140 & 3 & 4,0 \\
\hline
\end{tabular}

Pada Tabel 7, responden terbanyak ialah dengan pengukuran diastolik 70 sebesar 31 orang $(41,3 \%)$, sedangkan pengukuran diastolik 50 dan 100 masingmasing sebanyak 1 orang (1,3\%).

Tabel 7. Distribusi Karakteristik Responden Menurut Hasil Pengukuran Diastolik.

\begin{tabular}{ccc}
\hline TD Diastolik & $\mathrm{n}$ & $\%$ \\
\hline 50 & 1 & 1,3 \\
60 & 7 & 9,3 \\
70 & 31 & 41,3 \\
80 & 24 & 32,0 \\
90 & 11 & 14,7 \\
100 & 1 & 1,3 \\
\hline
\end{tabular}

Pada Tabel 8, responden dengan tekanan darah normal sebanyak 40 orang (53,3\%), diikuti responden dengan prehipertensi 22 responden (29,3\%), dan responden dengan hipertensi 13 orang $(17,3 \%)$.

Tabel 8. Distribusi Karakteristik Responden Menurut Hasil Pengukuran Tekanan Darah.

\begin{tabular}{lcc}
\hline Tekanan Darah & $\mathrm{n}$ & $\%$ \\
\hline Hipertensi & 13 & 17,3 \\
Pre-Hipertensi & 22 & 29,3 \\
Normal & 40 & 53,3 \\
\hline
\end{tabular}

Hasil analisis menggunakan uji Chi-
Square menyatakan nilai signifikansi 0,001 $(0,001<0,005)$ sehingga dapat disimpulkan $\mathrm{H}_{0}$ ditolak atau terdapat hubungan antara berat badan dengan tekanan darah pada siswa SMP di Kecamatan Pineleng.

Tabel 9. Hasil Uji Chi-Square

\begin{tabular}{cccc}
\hline $\mathrm{X}^{2}$ & df & $\mathrm{P}$ & Ket. \\
\hline 22,651 & 6 & 0,001 & $\begin{array}{c}\text { Ada } \\
\text { Hubungan }\end{array}$ \\
\hline
\end{tabular}

\section{BAHASAN}

Data hasil penelitian menunjukkan bahwa yang terbanyak ialah responden dengan berat badan overweight sebanyak 37 orang $(49,3 \%)$, diikuti dengan responden dengan obesitas sebanyak 22 orang (29,3\%) sedangkan responden dengan berat badan normal sebanyak 13 orang $(17,3 \%)$, dan responden dengan berat badan underweight sebanyak 3 orang (4\%). Dari data hasil pengukuran tekanan darah didapatkan responden dengan tekanan darah normal sebanyak 40 orang (53,3\%), diikuti responden dengan pre-hipertensi sebanyak 22 responden (29,3\%), dan responden dengan hipertensi sebanyak 13 orang $(17,3 \%)$.

Hasil uji Chi-Square menunjukkan terdapat hubungan yang signifikan antara berat badan dengan tekanan darah pada siswa SMP di Kecamatan Pineleng dengan nilai signifikan 0,001 atau (nilai $P=0,001$ $<0,05$ ) yang berarti $\mathrm{H}_{0}$ ditolak.

Hasil penelitian ini didukung oleh hasil penelitian Cossio-Bolanos et al. $^{12}$ tahun 2014 yang menyatakan bahwa remaja dengan berat badan lebih dan obesitas memiliki tekanan darah lebih tinggi dari remaja dengan berat badan normal. Dalam penelitian ini menunjukkan bahwa remaja dengan berat badan lebih dan obesitas memiliki nilai berat badan, IMT dan persentase lemak yang lebih tinggi; pada saat yang sama, mereka menunjukkan peningkatan nilai rata-rata tekanan darah bila dibandingkan dengan remaja dengan berat badan normal. Secara umum, 
penelitian telah menunjukkan bahwa anakanak dan remaja dengan tekanan darah tinggi lebih rentan untuk mengembangkan hipertensi arterial seperti pada orang dewasa. Kelebihan berat badan dan lemak tubuh selama pertumbuhan berhubungan dengan tingginya kadar plasma insulin, lipid dan lipoprotein. Selain itu, beberapa faktor risiko telah dikaitkan dengan gaya hidup, seperti kurangnya aktivitas fisik dan gangguan makan. ${ }^{12}$

Hasil penelitian ini juga sejalan dengan penelitian yang dilakukan oleh Dulskiene et al. $^{13}$ tahun 2014 yang menyatakan bahwa berat badan lebih, obesitas dan obesitas abdominal secara signifikan berhubungan dengan pre-hipertensi dan hipertensi pada anak sekolah di Lithuania. Dalam penelitian ini disebutkan bahwa tekanan darah tinggi dapat disebabkan oleh berbagai faktor resiko seperti faktor lingkungan, faktor genetik, dan interaksi antara faktor genetik dan lingkungan. Tekanan darah, plasma glukosa, dan lipid dapat meningkatkan dosis-dependen pada resiko kardiovaskular. Hasil penelitian terbaru menunjukkan bahwa kalsium/ kalmodulin-dependen kinase IV (CaMKIV) berperan esensial pada regulasi tekanan darah melalui kontrol aktivitas endothelial sintesis nitrit oksida. Penelitian lain juga melaporkan bahwa angiotensino-gen AGT $235 \mathrm{~T}$ allele merupakan faktor risiko independen untuk resistensi hipertensi. ${ }^{13}$

\section{SIMPULAN}

Berdasarkan hasil penelitian dan bahasan dapat disimpulkan bahwa terdapat hubungan bermakna antara berat badan dengan tekanan darah pada siswa SMP di Kecamatan Pineleng.

\section{DAFTAR PUSTAKA}

1. Lestari S. Faktor Risiko Penyebab Kejadian Obesitas pada Mahasiswa Fakultas Kedokteran Universitas Sumatera Utara Tahun 2011 [Skripsi]. Medan: Universitas Sumatera Utara; 2012.
2. Kotchen TA. Obesity-Related Hypertension: Epidemiology, Pathophysiology, and Clinical Management. American Journal of Hypertension. 2010;23(11):1170-8.

3. Ariani A, Sembiring T. Prevalensi Obesitas Pada Anak Sekolah Dasar di Kota Medan. Majalah Kedokteran Nusantara. 2007;40( 2):86-9.

4. Gungor NK. Overweight and Obesity in Children and Adolescent. J Clin Res Pediatr Endocrinol. 2014;6(3):12943.

5. Lumoindong A. Hubungan Obesitas dengan Profil Tekanan Darah pada Anak Usia 10-12 Tahun di Kota Manado. eBM. 2013;1(1):147-53.

6. Supartha M, Suarta IK, Winaya IBA. Hipertensi pada Anak. MKI. 2009;59(5):221-30.

7. WHO. Population-Based Approaches to Childhood Obesity Prevention. 2012. Avalilable from: http: www.who.int/dietphysicalactivity/chi ldhood/who_new_childhoodobesity_ prevention_27mov_hr_print_ok.pdf

8. Halbach SM, Flynn J. Treatment of Obesity-Related Hypertension in Children and Adolescents. Curr Hypertens Rep, March 2013, DOI 10.1007/s11906-013-0334-7.

9. Kussoy K, Fattimawali, Kepel B. Prevalensi Obesitas Pada Remaja Di Kabupaten Minahasa. eBM. 2013;1(2):981-5.

10.Riana R. Hubungan Penyesuaian Diri dengan Kualitas Hidup Pada Penderita Hipertensi. Pekanbaru: Universitas Islam Negeri Sultan Syarif Kasim; 2014.

11.Saing JH. Hipertensi Pada Remaja. Sari Pediatri. 2005;6(4):159-65.

12.Cossio-Bolanos $\mathbf{M}$, et al. Nutritional Status and Blood Pressure in Adolescent Students. Arch Argent Pediatr 2014; 112(4):302-7.

13.Dulskiene $\mathbf{V}$, et al. Association between Obesity and High Blood Pressure Among Lithuanian Adolescents: A Cross-Sectional Study. Italian Journal of Pediatics 2014;40:102. 